\title{
The Terrorist Risk Insurance ACt OF 2002: The Federal Government's Role in Addressing Losses Caused by Terrorism
}

\section{By Michael P.G. Stinziano}

Abstract: In response to problems associated with insuring against the risk of foreign terrorist attacks in the United States, Congress passed The Terrorist Risk Insurance Act of 2002 (TRIA) to help solve an availability and affordability crisis in the private marketplace for terrorism risk insurance. TRIA established a temporary three-year federal program that created a risk-sharing mechanism to provide private insurance companies with a tool to manage the allocation of their risk resulting from foreign terrorist attacks. The role of government in helping to provide financial protection from losses not served by private markets is not new, but protecting against terrorism risk is. TRIA and its possible alternatives remain a topic of considerable discussion and debate as our country continues to address the threat of terrorism in the United States. One important element of this analysis is to determine what permanent role, if any, the government should play in providing terrorism risk insurance to address the market failure that occurred after September 11. Another is to explore possible alternatives to the current temporary program.

Terrorism is unique. A single event can destroy your business, whether you are a target or not. This is a moving, morphing, constantly changing target.

Gail P. Norstrom,

Managing Director Property Practice Group, Aon Risk Services Company

(Hoffman 2003)

\section{General Overview}

For the vast majority of Americans, including insurance policyholders, costs associated with insuring against the risk of foreign terrorist attacks in the United States first became a reality with the disastrous events of September 11, 2001. As a result of the attacks, our government faced several major challenges, including how to respond to the failure of private insurance Michael P.G. Stinziano currently works in the Development Office of the Woodrow Wilson International Center for Scholars. Michael earned a Master of Public Administration degree from The George Washington University with a concentration in state and local government management. He is a member of the American Society for Public Administration. Michael earned a B.A. in Leadership Studies from the University of Richmond with a minor in business administration and a concentration in pre-law. markets to make terrorism insurance protection available to people and companies who needed full insurance coverage to start new construction projects valued at more than $\$ 25$ billion (Bush 2002). Perhaps an even more important concern was how to provide insurance coverage to those who may become victims of future terrorist attacks.

In response, Congress passed The Terrorist Risk Insurance Act of 2002 (TRIA), ${ }^{1}$ to help solve problems created by the lack of available and affordable terrorism risk insurance. The stated purpose of the law is:

To address market disruptions, ensure the continued widespread availability and affordability of commercial property and casualty insurance for terrorism risk and to allow for a transition period for the private markets to stabilize and build capacity while preserving State insurance regulation and consumer protections. (Federal Register 2003)

TRIA established a temporary three-year federal program that created a risk-sharing mechanism to provide private insurance companies with a tool to manage the allocation of their risk resulting from foreign terrorist attacks. ${ }^{2}$ However, critics allege that 
TRIA "has done very little to address fundamental issues", specifically the availability and affordability of terrorism risk insurance coverage, and that in the future TRIA will fail to adequately address the types of costs associated with the September 11 attacks (Business Wire 2003).

The key question is: should the federal government be in the business of helping the insurance industry provide terrorism risk insurance or would another alternative better serve this goal? While the appropriate role of government in helping to provide financial protection from losses caused by terrorist attacks remains a topic of considerable discussion and debate as implementation of TRIA moves forward, I believe that Congress should make TRIA a permanent program and adopt amendments to increase the effectiveness of the program.

\section{The Insurance Market}

In return for paying their premiums, Americans rely on insurance to help pay for large financial losses, like those the country experienced on September 11. The industry works by pooling the risks of many individuals and businesses and transferring them to an insurance company or other large insurance group. The insurance industry operates on the "Law of Large Numbers," which states that the larger the group of units insured, such as cars or commercial office buildings, the more accurate the predictions of loss will be (Insurance Information Institute 2004).

The private market for insurance and reinsurance is based on the spreading of risk or losses across as many entities as possible in order to decrease the financial impact of a contracted loss. Like most people, insurance companies want to decrease their exposure to any potential loss. To meet this goal, insurance companies create pools with other insurance companies across many lines of risk to cover potentially large exposures.

To help spread the risk of catastrophic losses among even larger groups, insurance companies buy reinsurance, frequently described as "insurance for insurance companies." A reinsurer typically assumes part of the risk and part of the premium originally taken by the insurer, known as the primary insurance company. Reinsurance effectively increases an insurer's capital and therefore its capacity to sell more coverage. The reinsurance business is global in nature, spreading payment for losses resulting from terrorist attacks in the United States to insurance companies located around the world (Insurance Information Institute 2004).

\section{Important Provisions of TRIA}

TRIA is a temporary federal program that will expire on December 31, 2005. TRIA compels insurance companies to offer terrorism coverage for commercial property and casualty insurance and, in the event of a terrorist attack, will provide federal funds to help insurance companies pay claims. TRIA does not limit the amount of premium an insurance company may charge for terrorism insurance coverage but does require clear disclosure of the premium amount.

Program coverage is limited to acts of foreign terrorism that result in more than $\$ 5$ million in property and casualty losses. Acts of domestic terrorism, like the bombing of the federal building in Oklahoma City, and acts of war that have been declared are not covered by TRIA. Before any federal funds can be paid, the Secretary of the Treasury, in concurrence with the Secretary of State and the Attorney General, must certify that an act of terrorism has occurred.

Under TRIA, the federal government, insurance companies, and insurance policyholders all share the risk of loss caused by foreign terrorism. The federal government is responsible for paying 90 percent of each insurance company's commercial property and casualty losses after the insurance company pays a "retention" of 10 percent of the commercial premium collected in 2004 or 15 percent of the commercial premium collected in 2005. Federal funds paid out under the program are capped at $\$ 100$ billion each program year. If the insurance industry pays claims exceeding $\$ 12.5$ billion in 2004 or more than $\$ 15$ billion in 2005 , the federal government pays all losses up to the annual program cap of $\$ 100$ billion. Insurance companies are not liable to pay losses in excess of $\$ 100$ billion a year. In some cases, the federal government may be reimbursed through surcharges paid by policy holders on property and casualty policies not to exceed 3 percent of the policy's annual premium (Goodwin Procter 2003). 


\section{The Context In which TRIA was Created}

The insurance marketplace prior to September 11 was facing difficult financial problems. The Return on Investment (ROI) and Return on Equity (ROE) for the industry were operating in negative numbers. The combined expense and loss ratio for the industry was approaching 121 percent or higher for specific lines of coverage. As a result, the industry was a candidate for a major shakeup in its allocation of surplus and pricing of risk (Hartwick 2003).

Because of both the economic difficulties the insurance market was facing and the terrorist attacks, following September 11, market coverage for commercial properties, general liability, workers' compensation exposures for business, and property perils resulting from terrorist attacks in the homeowners market became extremely difficult to find and expensive to purchase, adversely affecting the economy of the United States and the world.

\section{The Private Market for Terrorism \\ Risk Insurance before September 11}

Before September 11, commercial insurance policies routinely covered losses caused by terrorist attacks because "no insurer or reinsurer deemed the risk material enough to fashion an exclusion from it" (Rubock 2003). Insurance underwriters who price how much policyholders pay for insurance did not seriously consider the chance of enormous losses resulting from acts of terrorism in the United States. Unlike insurers in other countries, ${ }^{3}$ insurance companies in the United States routinely included terrorism risk insurance coverage in insurance policies but did not adequately price for terrorism risk in the policy premiums. Even with the earlier attack on the World Trade Center and the Oklahoma City bombing, insurance underwriters did not believe that terrorist acts were likely to occur in the United States. Historically, insurance companies had always included payment for damages caused by terrorists, but never included coverage in property and casualty insurance policies for damage caused by "war, civil war or civil commotion" (Swiss Re 2002).

\section{Insurance Company ACtions Involving Terrorism Risk AFTer SePtember 11}

The terrorist attacks not only resulted in the biggest insured catastrophe ever, but also the most complex because so many different lines of insurance -including business interruption, property, automobile, aviation, life, workers' compensation, event cancellation, and aircraft hull insurance-were involved. Fortunately, the insurance industry was able to pay for the historic losses resulting from the terrorists' attacks on September 11, and paid claims totaling more than $\$ 40$ billion (Insurance Information Institute 2002).

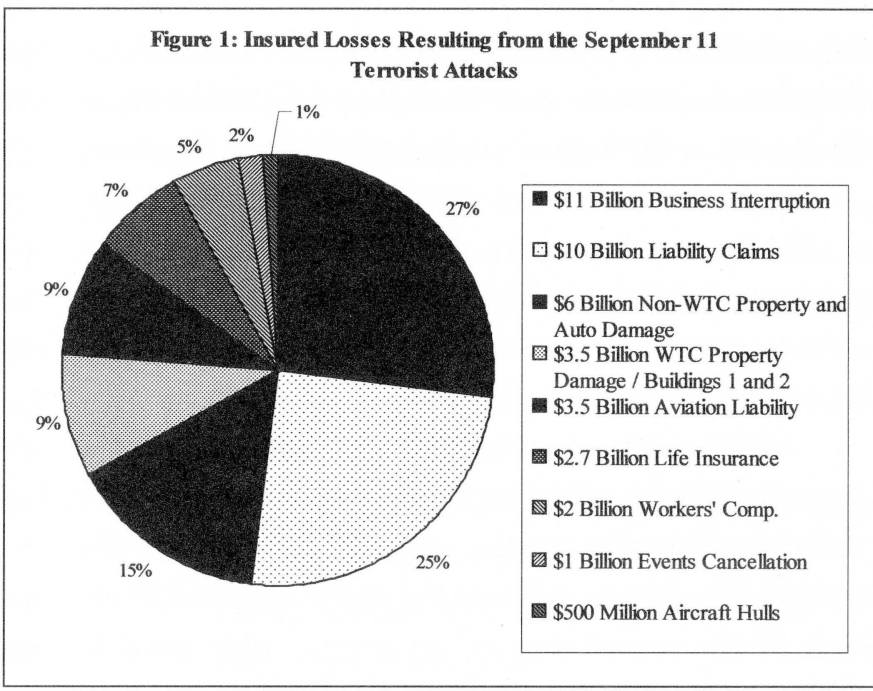

Source: Information Institute, 2002

The losses that resulted from the terrorist attacks compelled the industry to fundamentally review its risk acceptance position and to reduce and limit coverage to avoid unmanageable exposures in the future (Swiss Re 2002). A primary interest of insurance companies is to protect their solvency. Accordingly, after September 11, "insurers shifted the terrorism risk to property owners and business" with most companies deciding not to offer terrorism risk insurance coverage (Hillman 2002).

In addition, reinsurance companies began to exclude coverage for losses caused by terrorist attacks and eliminated coverage for future losses caused by terrorism "because the predicted losses of the September 11 claims [exhausted] upwards of onequarter of the reinsurance industry's surplus" (Saxton 2002). Like insurance companies, reinsurance 
companies had failed to accurately price for terrorism risk in the United States.

\section{The Effect of Terrorism on the Market}

Because the amount of future losses caused by terrorism is unpredictable, the private market, particularly insurers, faced new and complex challenges in pricing policies that included coverage for the types of losses that were paid following the terrorist attacks of September $11 .^{4}$ Perhaps the most important difference between pricing coverage for terrorism risk insurance as opposed to other risks is the difficulty of pricing losses that result from intentionally destructive human behavior. Because that behavior can vary with changing human motivations, measurement of expected losses, particularly claim frequency, is difficult to estimate (American Academy of Actuaries 2003). Making terrorism risk coverage available at a price most policyholders can afford is a particularly difficult dilemma because of the nature of terrorism and the inability to measure the risk associated with it.

Additionally, in attempting to determine the financial risk involved in paying for losses caused by individual terrorist attacks, actuaries, "who assemble and analyze data to estimate the probability and likely cost of the occurrence of an event," also need to determine the likelihood of the threat that future attacks will occur (U.S. Department of Labor 2004).

As was the case in the attacks of September 11, individual events can affect the entire economy and the incurred damage may be spread across many different lines of business (Swiss Re 2002). Terrorism is "highly diverse in terms of its instigators, motives, dimensions, targets and outcome" thus "the ability to predict terrorism [is] more or less viewed as random"s (Swiss Re 2002).

The result of the difficulties the insurance market experienced in pricing terrorism risk was that, although terrorism policies remained available on an extremely limited basis, terrorism policies became "very expensive, terms [were] restrictive and coverage limits [were] frequently too low, when it [was] available at all" (Saxton 2002). For the few companies that still offered terrorism insurance, the premiums jumped 300 to 400 percent (Spinner 2003). Owners of property considered likely terrorist targets could not purchase terrorism risk insurance, thus making them in technical default of their mortgage agreements with lenders and their property subject to foreclosure. In cases where property owners were offered insurance, the policy came with much higher premiums. In a short period of time it became obvious that the interests of insurance companies were in direct conflict with the interests of their policyholders who needed terrorism insurance.

\section{Government Actrons Involving Terrorism \\ Risk INSURANCE AFTER SFPTEMBER 11}

Given the lack of a private insurance market where people could purchase terrorism insurance and the resulting threat to the economy, Congress decided to consider a federal solution to the problem. Mark J. Warshawsky, Deputy Assistant Secretary for Economic Policy, United States Department of the Treasury, stated that "the lack of coverage and high premium rates imply a drag upon our economy and a burden to the nascent recovery, including the potential for a loss of even more jobs" and "the cost of lost and postponed investment opportunity is potentially large for future economic growth" (Office of Management and Budget 2002).

As a result of intense efforts by economic interests advocating the need for federal government involvement, President Bush became personally involved in advocating for a solution to the problem, urging Congress to pass TRIA "to ensure the continued availability of insurance for terrorist-related acts while encouraging the private sector to build new capacity" (Office of Management and Budget 2002). After considering a variety of plans, the House of Representatives responded quickly to the President and passed terrorism insurance legislation on November 29, 2001 (Saxton 2002). Debate about the appropriate role for government involvement in the insurance marketplace took more time in the Senate, however, partially because of partisan disagreement that developed over the inclusion of wide-ranging tort reforms in the final House-passed version of TRIA. Ultimately, after more than a year of debate, the House and Senate reached agreement on a compromise in November 2002, and President Bush quickly signed TRIA into law (Fisher 2002). 


\section{Government Participation in Insurance Programs}

The federal government's involvement in establishing a program to ensure the availability and affordability of certain lines of insurance is not a new concept. Prior to September 11, thirteen insurance programs ${ }^{6}$ involving the federal government existed in the United States to "ensure that insurance will be available to cover risk that the private sector has been unable or unwilling to cover by itself' (McCool 2001). These programs range from being entirely controlled and managed by the federal government to being established by the government but run with no clear government involvement ( $\mathrm{McCool} 2001$ ).

Historically, the main reason for the government to be directly involved in providing or facilitating insurance coverage was to provide available and affordable insurance in those instances when the private market failed to assume the responsibility for insuring a particular risk. Government also becomes involved when private insurers offer the coverage at a price that most policyholders cannot afford. The major distinction between the private insurance industry, which is motivated by the need to make a profit, and government insurance prograns, which are not profitoriented, is that government insurance programs are often initiated with the intent of achieving other economic or social goals (Feldman 2002).

The features of government insurance programs vary depending on the programs' purpose and structure. Although each of these insurance programs seeks to address a particular shortcoming in the private market in providing a specific type of insurance and to promote an economic or social goal, "insurance programs are organizationally complex and pose a significant number of managerial and political challenges" (Feldman 2002). TRIA does not differ from other government insurance programs in this regard.

\section{Congressional Intent in Enacting TRIA}

Congress enacted TRIA as a short-term solution for the lack of available coverage against losses caused by foreign terrorist attacks and the stagnant economic conditions the country faced after September 11 . Because Congress created TRIA as a temporary program, both the federal government and the private sector remain engaged in ongoing discussions on how best to address the need for providing terrorism risk coverage after TRIA expires at the end of 2005. One of TRIA's provisions requires an ongoing policy analysis of TRIA, which is currently being conducted by the Treasury Department, and also an analysis of possible viable alternatives to TRIA. The General Accounting Office is conducting a similar study for Congress.

\section{Comparing TRIA's Results to Date Against the Stated Congressional Purpose}

Because the program is relatively new, judging the overall effectiveness of TRIA may be premature. However, it is possible to compare results to date against the purposes that Congress stated in Title 1, Section 101B: Purpose of the Act. The four major purposes of TRIA can be described as:

- Provide availability of terrorism risk insurance;

- Improve affordability of terrorism risk insurance;

- Promote the stability of the private terrorism risk insurance market; and

- Preserve state insurance regulation and consumer protections.

Research and literature to date indicate TRIA has been a partial success in that it has made terrorism risk insurance available in a market that had failed to provide coverage prior to TRIA's enactment; however, the affordability of terrorism risk insurance currently remains problematic for many policyholders (Hoffman 2003). The temporary nature of TRIA is also motivating private insurance companies to find a way to re-establish the stability of the private terrorism risk insurance market (Tillinghast-Towers Perrin 2003).

\section{Availability and Affordability}

The provisions of TRIA that nullified previous state-approved exemptions to providing terrorism risk coverage and the "make available" requirement of the Act directly address the problems that insurance policyholders were experiencing with the lack of availability of terrorism risk insurance. As a result, 
TRIA makes terrorism coverage available to every commercial insurance policyholder who wants to purchase it. However, TRIA placed no restrictions on pricing for terrorism risk insurance coverage as long as the pricing meets state insurance requirements of not being "excessive, inadequate, or unfairly discriminatory" (National Association of Insurance Commissioners 2003).

Some potential policyholders complain that pricing is widely divergent and that some insurers do not want to offer the product. According to surveys conducted by the Council of Insurance Agents and Brokers, whose members write 80 percent of the commercial property/casualty premiums annually, the price of terrorism coverage runs anywhere from 2.5 percent to 300 percent of the underlying premium with the median running about 12 percent and perhaps 18 percent in areas regarded as higher risk. Compared with stand-alone terrorism policies, the TRIA-backed coverage generally costs less and provides higher coverage limits (Hoffman 2003). Despite its availability, the surveys show that many commercial interests are not buying terrorism insurance at all due to its high cost although the relatively affordable cost of purchasing terrorism coverage for developers of commercial projects has spurred the growth in new construction that many supporters of TRIA had hoped for (Council of Insurance Agents and Brokers 2003).

\section{Promote Stability in the Private Terrorism Risk Insurance Market}

In an effort to help promote stability in the private terrorism risk insurance market, insurance companies are exploring ways to work together to help provide terrorism risk coverage after TRIA sunsets in 2005. These efforts, including exploring pool arrangements, capital offerings to increase surplus, and language modifications that clearly define the loss exposure that should be covered, are still a work in progress with no specific results evident to date. Because the private insurance market has not yet responded to the need to provide terrorism risk insurance following the expiration of the program, the temporary nature of TRIA in its present implementation results in charges that TRIA is "not doing what it was supposed to do" (Oster and Starkman 2003).

\section{Preserve State Insurance Regulation and Consumer Protections}

According to all reports, TRIA is meeting the purpose of preserving state insurance regulations and consumer protections. Iowa Insurance Commissioner Terri Vaughan, past President of the National Association of Insurance Commissioners, was actively involved in working with the leadership of both the U.S. House and Senate in drafting the provisions of TRIA that affect state insurance regulations and consumer protections. Insurance commissioners across the county have a good relationship with officials at Treasury who are working to implement the provisions of TRIA (National Association of Insurance Commissioners 2003).

Cost

One additional way of judging the success of TRIA not mentioned in the purposes for which Congress passed the legislation will be an eventual determination regarding the cost effectiveness of the program. While the ultimate cost of TRIA will depend on the severity of future terrorist attacks in the United States, costs to date have been minimal (Congressional Budget Office 2001).

\section{Alternatives to TRIA}

In addition to TRIA, there are at least three other ways (two involving the government and one involving private parties) to provide terrorism insurance:

- TRIP (Terrorist Risk Insurance Program), where the federal government establishes a new program to act as a direct insurer providing terrorism coverage to policyholders and paying for losses caused by terrorism;

- Pool Re, where the federal government acts as a reinsurer of private insurance companies; and

- A private voluntary pool with no federal government involvement.

\section{Alternative One: TRIP, The Federal Government as Direct Insurer}

One potential alternative that has been suggested would be to replace TRIA with a new program where 
the federal government acts as the direct insurer providing terrorism coverage to policyholders and paying for losses caused by terrorism (Reinsurance Association of America 2002). Under this scenario the federal government would provide terrorism risk insurance to policyholders in direct competition with, or to the exclusion of, insurers in the private market. In some of the thirteen insurance programs created by federal statute that cover risks where insurance is not generally available in the private market, the federal government assumes the role of a primary insurance company providing direct insurance coverage to policyholders. While the sources of funding vary from program to program, in one way or another the federal government subsidizes all thirteen programs, five with direct payment. In addition, the ability to pay claims in four of the programs is guaranteed by the full faith and credit of the U.S. government.

Operational details of the new program could be modeled after the Aviation and Maritime-War Risk Programs, which insure against losses resulting from war, terrorism and other hostile acts when commercial insurance is unavailable on reasonable terms and conditions, and continued air and maritime service is determined to be in the interest of U.S. policy. The new program could also be modeled after the National Insurance Development Program (Riot Re), which effectively insured against property losses caused by riot and civil disorder and provided property owners with affordable insurance in high-risk urban areas following riots in cities across the country during the 1960s and 1970s. After insurance companies were able to reestablish a market for urban property insurance during the 1980 s, Congress decided to eliminate the Riot Re program (McCool 2001).

Based on the experience of the thirteen insurance programs currently sponsored by the federal government, TRIP could be an effective but potentially expensive program. If, however, in an effort to avoid problems with the economy that might result from not having terrorism coverage, Congress were willing to appropriate the funds necessary to operate the program, authorize the subsidies necessary to make premiums affordable, and guarantee payment of losses caused by future terrorist attacks, TRIP could be an effective alternative to TRIA.
As a result of Congressional creation of TRIA. support for a new program like TRIP is highly improbable. The current administration and Congress have no desire to increase the government bureaucracy; instead, the goal is to make the marketplace work independent of government intervention.

The costs associated with allowing the federal government to provide terrorism insurance directly to policyholders would be high, especially if the government attempts to establish premiums at a level that policyholders would be willing to pay. In addition, there is a very real danger of adverse selection against that program in that only policyholders located in a large urban area will purchase insurance. This will lower the available risks in the pool and significantly increase the cost of the program. Also, setting up the bureaucracy necessary to underwrite, administer, and pay claims associated with losses caused by terrorist attacks, in addition to paying for the losses themselves, is likely to be prohibitively expensive compared to other alternatives.

In setting up a government program to provide terrorism risk insurance coverage directly to policyholders, the federal government would be required to compete directly with the private insurance industry for employees with the skills and experience necessary to carry out the insurance operations. If the government decided not to directly employ people to carry out this program, the administration of the program could be outsourced to insurance companies whose employees have the underwriting, actuarial, administrative, and claims handling skills that the program would require. In either case, the government would be incurring unnecessary expenses to duplicate or pay for skills that are already available in the private sector.

\section{Alternative Two: Pool Re, The British MOdEL}

This alternative is based on insurance plans in other countries, including the United Kingdom, Australia, and Pakistan, that have been implemented to provide coverage for terrorist attacks. Unlike TRIA, participation in this alternative would be strictly voluntary with minimum government involvement. This alternative could be modeled directly on the operations of the Pool Reinsurance Company L Limited, 
a mutual insurance company established and regulated in the same manner as any insurance company in Britain.

Pool Re is required, for example, to maintain a solvency margin in accordance with standard British regulations. By its charter, it is authorized only to write reinsurance relating to terrorist risks on commercial property insurance. Where it differs from standard insurers and reinsurers is that the liabilities of Pool Re are reinsured by the government of the U.K., to which Pool Re pays a reinsurance premium and from which it will recover any claims that exceed its resources (Tillinghast-Towers Perrin 2003).

Any insurance company operating in Great Britain that offers commercial property insurance may become a member of Pool Re; however, insurers are not required to become members. At the end of 1999 , Pool Re had 213 members (Tillinghast-Towers Perrin 2003). If an insurance company chooses not to become a member, it has three options if it wishes to write commercial insurance:

- It may offer insurance without protection against terrorism;

- It may try to find terrorism reinsurance in the private market; or

- It may operate without reinsurance protection. (Tillinghast-Towers Perrin 2003)

Pool Re pays its claims using a combination of internal and external resources, arranged in layers. First, accumulated underwriting profits are used. If these are exhausted, Pool Re may call for an assessment on its members of up to 10 percent of their current year premiums. If this is still insufficient, Pool Re may draw on any investment income it has accumulated to pay claims (Tillinghast-Towers Perrin 2003). The British government pays any claims that remain. There is no limit to the amount of this government guarantee. In Britain, no new legislation was needed to set up Pool Re. However, in order to enable Pool Re to carry out its role, special legislation, the Reinsurance (Acts of Terrorism) Act of 1993, was required to authorize the British Secretary of State to enter into the reinsurance contract between Pool Re and the government (Tillinghast-Towers Perrin 2003). Congress could pass similar legislation giving the federal government responsibility to act as a reinsurer for private insurance companies in the United States.

Because participation in Pool Re is voluntary and the British government provides no direct subsidy to lower terrorism insurance premiums (although the government guarantee to pay residual claims is an indirect subsidy that will lower premiums) coverage remains unaffordable for many policyholders in Britain. A plan based on the Pool Re model could help make terrorism insurance available in the United States but would do nothing to set premiums that policyholders would be able to afford and would therefore fail to meet one of the major goals that Congress set for an effective terrorism risk insurance program.

During early consideration of TRIA in the House of Representatives, the insurance industry gave its unanimous support for a draft proposal patterned after Pool Re. Within a few days, the White House informed Congressional leaders of its strong opposition to the proposal because Pool Re is permanent and the federal government's guarantee to pay claims is unlimited. As a result, any alternative based on the Pool Re model is not politically feasible at this time.

Even though the costs associated with the operations of Pool Re have been described as reasonable because the insurance industry and the British government share costs, the unlimited exposure of the British government in the event of catastrophic losses caused by a terrorist attack is troublesome. A plan based on the Pool Re model that provides unlimited exposure to the United States government could be cost prohibitive because of the possibility of future catastrophic losses caused by terrorist attacks in the United States.

\section{Alternative Three: Private Voluntary Pool}

One additional alternative that merits consideration anticipates no role for the federal government in providing for terrorism risk insurance coverage. The American Insurance Association (AIA) is a property and casualty insurance trade association that represents more than 424 insurance companies that write more than $\$ 103$ billion in premiums each year. AIA is currently exploring proposals to develop the financial and organizational specifications of a 
private terrorism reinsurance pool, as opposed to an insurance pool involving government participation or one requiring mandatory participation by insurers, which could only be established by the passage of a federal law (2003). The private voluntary pool "would provide a layer of shared industry responsibility for layers of loss above the levels which individual companies wish to retain, and below the thresholds for federal reimbursement provided by [TRIA]" (American Insurance Association 2003).

The AIA anticipates that "to be successful, the pool must provide equitable and competitively neutral treatment for all participating carriers - with respect to both premiums charged and losses reimbursed regardless of their size, financial strength, mix of business, and geographical diversity" (American Insurance Association 2003). Insurers are interested in exploring the establishment of a private voluntary insurance pool to address what the AIA perceives as "significant limitations" to TRIA, including the fact the TRIA ends in three years, coverage under TRIA is limited to foreign terrorism events, and the amount a company must pay before receiving federal payment can be significant.

The measure of the effectiveness of a private voluntary pool would be based on its ability to provide terrorism risk insurance for policyholders that want to purchase the coverage. A private voluntary pool would start faster than a mandatory pool because a voluntary approach does not need the broad consensus on concept or design that a mandatory pool would. The voluntary pool approach also provides some exposure-sharing and risk diversification for participants.

On the other hand, a voluntary pool does not spread risk or funding support as broadly as a mandatory pool would. Other disadvantages are that policyholders of non-participating insurance companies will not be protected, coordination with the expiration of TRIA will require careful design, and provisions providing for participants to enter and exit the pool will be complex. Like TRIA, a private voluntary pool would make terrorism risk insurance coverage available but only to the policyholders of companies that decide to participate in the pool, and the high cost of terrorism coverage is likely to remain a problem for many policyholders.
Given the intention of the Bush Administration and Congress during consideration of TRIA that whatever federal program was established would be temporary, the concept of a private voluntary pool is likely to win widespread government support. TRIA was limited to three years with the expectation that the insurance industry would create private market solutions like a private voluntary pool after that time. State insurance regulators, who are familiar with insurance pools that provide homeowner and automobile insurance, are also likely to give strong support to a well-run private voluntary pool. No federal or state legislation would be needed to create a private voluntary pool.

Costs to the government to implement and administer a private voluntary pool would be virtually non-existent. The only possible cost involved might be the loss of tax revenue on the assets the pool would set aside to pay claims (assuming that the insurance industry could convince the Internal Revenue Service that the pool is a tax free entity).

\section{IMPROVING THE EFFectiveness of TRIA}

Overall, I believe that amending TRLA best meets the goals of creating a permanent program, supporting the economy, and protecting against a devastating economic result from future terrorist attacks. Of course, amending TRIA or establishing a private voluntary pool makes insurance available but neither option solves the problems of policyholders who can not afford to pay for the premiums to insure themselves against losses caused by terrorist attacks. But establishing programs like TRIP or Pool Re, which make terrorism risk insurance more affordable to policyholders as a result of government subsidies, is not realistic because of potentially exorbitant costs to the federal government and lack of political support.

Consensus has yet to develop on whether and how to improve the effectiveness of TRIA. Some believe that TRIA should sunset on December 31,2005, as originally planned by Congress; however, many of the constituent groups that supported TRIA initially have decided to lobby Congress to make TRIA permanent and adopt several amendments to improve its effectiveness.

William Warfel, Professor of Insurance and Risk Management at Indiana State University, is a 
particularly vocal proponent of making TRIA permanent and amending the original legislation to increase its effectiveness. Professor Warfel argues that TRIA needs to be re-enacted, notwithstanding industry efforts to form a voluntary insurance pool to provide terrorism insurance coverage, to achieve long-term market stability and to minimize the potential cost to the federal government of a future act of terrorism (2003).

Weighing all of the factors involved, I believe that Congress should make TRIA a permanent program and adopt the following amendments, which are supported by Professor Warfel and others:

- Allow for the creation of a tax-free catastrophe reserve fund paid for by a surcharge on commercial policyholder rates;

- Make the purchase of terrorism risk insurance compulsory for all commercial policyholders; and

- Expand the lines of property/ casualty insurance covered by the program.

While no one can be certain how Congress will respond to suggestions like these, suggestions for improving the effectiveness of TRIA will continue to be debated as alternatives to return stability to the terrorism insurance marketplace are explored. Absent another terrorist attack in the United States, Congress is not expected to take up the issue of terrorism risk insurance again until 2005 - just before TRIA is scheduled to end. Finding a solution, in the words of Congressman Michael Oxley, Chair of the House Financial Services Committee and Chief Sponsor of TRIA, is "critical for America," In originally urging the House to adopt TRIA, Congressman Oxley said, "We need it to protect jobs, protect our economy, and protect the American people against future terrorist attacks" (2002).

It will be no different, and perhaps even more important, if a future round of terrorist attacks occurs in or against the United States.

\section{Notes}

${ }^{1}$ H.R. 3210, 107th Cong., 2nd Sess.
${ }^{2}$ TRIA defines terrorism as "an act that is violent or dangerous to human life, property, or infrastructure; that has resulted in damage within the United States... and that has been committed by individual(s) on behalf of any foreign person or foreign interest, as part of an effort to coerce the U.S. civilian population or to influence the policy or affect the conduct of the U.S. government by coercion" (Department of the Treasury 2003).

${ }^{3}$ For example, the UK created a terrorism risk insurance mechanism called Pool Re in response to "the international reinsurance market withdrawn capacity as a consequence of IRA terrorism in the 1990's, which, in turn, led to a state supported solution: limited private cover with addition excess cover made available for insurance companies" (Swiss Re 2002).

${ }^{4}$ Prior to the attacks on the World Trade Center and the Pentagon, insurers in the United States had little or no historical information on which to base pricing for insurance coverage for losses caused by acts of terrorism (American Academy of Actuaries 2003).

${ }^{5}$ Terrorism risk in many ways closely parallels natural catastrophe risks such as earthquakes, storms, and floods yet "even natural disasters have a recorded history of a century or more, allowing insurers to predict aggregate potential losses over time" (Saxton 2002).

${ }^{6}$ Catastrophic Nuclear Accident Program; Overseas Private Investment Corporation (OPIC) Political Risk Insurance; National Insurance Development Program (Riot Re); National Flood Insurance Program; Bank Insurance Fund; Aviation-War Risk Insurance Program; Federal Crop Insurance Program; Maritime War-Risk Insurance Program; National Credit Union Share Insurance Program; Pension Benefit Guaranty Corporation Insurance; Savings Association Insurance Fund; Service-Disabled Veterans Insurance Program; National Vaccine Injury Compensation Program (United States General Accounting Office 2002). 


\section{REFERENCES}

American Academy of Actuaries. 2003. Report to NAIC Terrorism Insurance Implementation Working Group on Ratemaking Issues Related to The Terrorism Risk Insurance Act. March 14.

American Insurance Association. 2003. Terrorism Risk Insurance Act of 2002: Outline. Conference Compendium. AIA Emerging Issues 2003. January $21-23$.

Bush, George W. 2002. President Signs Terrorism Insurance Act. www.whitehouse.gov.

Business Wire. 2003. Conning: Terror Insurance Act does not solve Problems, Placebo Effect Wears Off. February 24. www.conningresearch.com.

Congressional Budget Office. 2001. Estimated Budgetary Impact of H.R. 3210. Washington, DC: Government Printing Office.

Council of Insurance Agents \& Brokers. 2003. Many Commercial Interests Are Not Buying Terrorism Insurance, New CIAB Survey Shows, March 24.

Department of the Treasury. 2003. Terrorism Risk Insurance Program. 31 CFR Part 50, RIN 1505AA96 (February 25).

—. 2003. Terrorism Risk Insurance Program. 31 CFR Part 50, RIN 1505-AA98. (April 15).

Federal Register. 2003. Department of the Treasury. Department Offices; Terrorism Risk Insurance Program; Interim Final Rule and Proposed Rule. Vol. 68(40). January 29.

Feldman, Ron J. 2002. Government Insurance. In The Tools of Government, A Guide to the New Governance, ed. Lester M. Salamon. Oxford University Press: New York.

Fisher, Peter R. 2002. Interim Guidance Concerning New Statutory Disclosure and Mandatory Availability Requirements of the Terrorism Risk Insurance Act of 2002. December 3.
Goodwin Procter. 2003. The Terrorism Risk Insurance Act of 2002: Coverage in a Post-9/11 World. Client Alert. February 6.

Hartwig, Robert P. 2003. Terrorism Insurance: What did 9/11 Actually Mean for the Insurance Industry? Insurance Information Institute presentation. Terrorism Risk Management Conference. New York, New York. January 28.

Hillman, Richard J. 2002. General Accounting Office. Terrorism Insurance - Rising Uninsured Exposure to Attacks Heightens Potential Economic Vulnerabilities. Testimony before the Subcommittee on Oversight and Investigations, Committee on Financial Services. House of Representatives.

Hoffman, Mark A. 2003. TRIA's transience a problem. Terrorism Risk Assessment and Insurance Coverage Seminar. Business Insurance. June 23.

Insurance Information Institute. 2002. 9/11 and Insurance, One Year Later; Terror Attacks Most Complex Disaster in History. Insurance Letter - Special 911 Edition. www.insurance-portal.com.

Insurance Information Institute. 2004. Media Glossary. www.iii.org/media/glossary.

McCool, Thomas J. 2001. General Accounting Office. Terrorism Insurance: Alternative Programs for Protecting Insurance Consumers. Testimony Before the Senate Committee on Banking, Housing, and Urban Affairs. United States Senate.

National Association of Insurance Commissioners. 2003. Report on Interim Activities. Terrorism Insurance Implementation (EX) Working Group. New York, New York, June 21.

Office of Management and Budget. 2002. H.R. 3210 - Terrorism Risk Protection Act. www.whitehouse.gov/omb.

Oster, Christopher and Dean Starkman. 2003. AIG's CEO Questions Terror-Insurance Costs. Wall Street Journal, February 14. 
Oxley, Michael G. 2002. House Committee on Financial Services. Oxley to Join President for Signing of Terrorism Insurance Legislation. November 25.

Reinsurance Association of America. 2002. Options for Addressing Terrorism Risk. E-mail from Mary Seidel. (Retrieved March 3, 2003).

Rubock, Daniel B. 2003. CMBS: Moody's Approach to Terrorism Insurance After the Federal Backstop. Moody's Investors Service.

Saxton, Jim. 2002. Economic Perspective of Terrorism Insurance. Testimony before the United States Congress, Joint Economic Committee, May. www.house.gov/jec/.

Spinner, Jackie. 2003. Firm's Rejecting Terror Coverage; Insurers Say Few Companies Feel Risk, Accept Costs. Washington Post, February 25.

Swiss Re. 2002. Terrorism - Dealing with the new Spectre. Swiss Reinsurance Company, Zurich. www.swissre.com.

Tillinghast-Towers Perrin. 2003. Proposal to Develop the Financial and Organizational Specifications of a Terrorism Reinsurance Pool, http:// www.towersperrin.com/reinsurance/default.htm.

United States Department of Labor. 2004. Bureau of Labor Statistics - Occupational Guide. www.bls.gov/oco/ocos041.htm (Accessed March 4, 2004).

United States General Accounting Office. 2002. Thomas J. McCool. Summary of insurance programs sponsored by the federal government. Testimony before the Senate Committee on Banking, Housing and Urban Affairs. United States Senate.

Warfel, William J. 2003. Rules \& Regulations: Amending TRIA. Risk Management Magazine, June 16.

Warshawsky, Mark J. 2002. Economic Impact of the Lack of Terrorism Risk Insurance. Testimony before the Financial Services Subcommittee on Oversight and Investigation. United States House of Representatives. 